\title{
Przedmiot-relikwia a postać Jana Pawła II w krakowskim kontekście muzealnym ${ }^{1}$
}

\author{
An Object / A Relic and a Figure of John Paul II in the Context of \\ Kraków's Museums
}

\section{Abstract}

This article discusses different museum exhibitions and narratives related to John Paul II within Kraków's cityspace. The cult of this recently canonized Catholic saint (2014) is very popular in Poland, particularly in Kraków, which is called the 'Pope's City'. The paper focuses on items-relics objects that were used or touched by John Paul II - and are nowadays exhibited in various museums in Kraków. These material objects are a means of creating local stories about John Paul II and his sanctity. The author compares two sets of items exhibited in two different museums: The Cardinal Karol Wojtyła Room exhibited in the Saint John Paul II's Centre and the Pope's Helicopter exhibited in the Polish Aviation Museum. The analysis reveals diverse strategies and uses of objects-relics related to the museumification and sacralization of the figure of John Paul II.

Keywords: museumification/musealization, museums, John Paul II, Kraków

Kraków był miastem, do którego w sierpniu 1938 roku wprowadził się osiemnastoletni Karol Wojtyła, rozpoczynający wówczas studia polonistyczne na Uniwersytecie Jagiellońskim. Był również miastem, z którego wyjechał na konklawe

1 Niniejszy artykuł powstał na podstawie fragmentu mojej pracy magisterskiej dotyczącej kultu relikwii św. Jana Pawła II w Krakowie, napisanej pod kierunkiem dr hab. Moniki Golonki-Czajkowskiej w roku akademickim 2016/2017. Materiał empiryczny natomiast został uzyskany podczas dwuletnich etnograficznych eksploracji terenowych w obrębie omawianego miasta w latach 2015-2017, opartych głównie na obserwacji uczestniczącej i wywiadach. W tym miejscu chciałbym również serdecznie podziękować Pani profesor Monice Golonce-Czajkowskiej za ponaddwuletnią współpracę oraz wsparcie merytoryczne udzielone mi podczas tworzenia wspomnianej pracy. 
do Rzymu w październiku 1978 roku pięćdziesięcioośmioletni kardynał Karol Wojtyła i do którego potem siedmiokrotnie powrócił na krótkie pobyty już jako papież Jan Paweł II. Czterdzieści lat życia Wojtyły w Krakowie i siedem odwiedzin Krakowa przez Jana Pawła II wystarczyły, by obecnie mówić o tym mieście jako o „papieskim Krakowie”. Mieście, które samo w sobie jest już zmitologizowanym palimpsestem i w sieć którego wpisuje się kolejna warstwa znaczeń związana z osobą papieża.

Niniejszy artykuł wpisuje się w antropologiczne badania kultu św. Jana Pawła II w Polsce (zob. Brzozowski 2013, 2014; Kubik 1994; Klekot 2007; Owczarek 2006), który niewątpliwie już za życia stał się bohaterem kulturowym (por. Łozińska 1990, 1992; Zowczak 1987). Ten wątek badawczy wygląda również ciekawie w kontekstach lokalnych, szczególnie zaś przestrzeni miejskiej Krakowa, postrzeganego jako „miasto papieskie” (zob. Niedźwiedź 2009, 2017a, 2017b). Chciałbym w ramach tego tematu szczególnie pochylić się nad procesem kreowania opowieści o Janie Pawle II w przestrzeniach krakowskich wystaw muzealnych i spojrzeć na niego zwłaszcza przez pryzmat obiektu muzealnego.

Kluczem moich poszukiwań i analiz są zatem „relikwie”, czyli te przedmioty, których święty używał za życia, lub takie, które dotknęły jego ciała (za życia lub po śmierci). Takie właśnie rzeczy, relikwie i cenne pamiątki zarazem, można zobaczyć na kilku krakowskich wystawach muzealnych, które są specjalnie dedykowane osobie Karola Wojtyły (Jana Pawła II). Muzea te są równocześnie atrakcją turystyczną, odkrywającą przed swoimi gośćmi fragment opowieści o religijnej i sakralnej historii Krakowa, prezentowaną przez postać świętego. Eksponaty ukazywane gościom na muzealnych wystawach nie tylko przedstawiają cenne dla danej instytucji przedmioty, ale również troskę o autentyczność ukazywanych obiektów oraz prowadzoną muzealną narrację. Owa autentyczność, na co wskazują teoretycy badający kulturowy fenomen turystyki (zob. MacCannell 2002; Urry 2007; Wieczorkiewicz 2008), jest kluczową kategorią w turystycznym widzeniu i pojmowaniu świata.

Wystawę muzealną traktuję jako świadomie stworzoną przez konkretne instytucje czy osoby niewerbalną opowieść, rodzaj wizualnej i doświadczalnej narracji, której głównym środkiem wyrazu jest przedmiot. Ten zaś nie jest wyłącznie milczącym obiektem (Vergo 2005: 319-320), lecz materią, z której konstruuje się daną muzealną opowieść. W takim ujęciu przedmiot-relikwia, poza znaczeniem, jakie niesie sam w sobie, nabywa nowego, szerszego znaczenia w kontekście całej muzealnej narracji. Kreowanie takich znaczeń i ukazanie dwóch różnych strategii ich nadawania będę starał się przedstawić na dwóch przykładach, traktując je jako jakościowe studia przypadków - pokoju kardynała Wojtyły w Muzeum przy Centrum Jana Pawła II w Krakowie oraz Śmigłowca Papieskiego w Muzeum Lotnictwa Polskiego w Krakowie. 


\section{Muzealne życie obiektu}

Przedmioty umieszczone na wystawie muzealnej rozpoczynają swoje nowe, muzealne życie. Otrzymują one wówczas również nowe znaczenie i funkcje - stają się pośrednikami między widzem a swoją szeroko rozumianą reprezentacją.

Według Krzysztofa Pomiana obiekty są podstawowym i głównym środkiem wyrazu wystawy i to właśnie one uczestniczą w wymianie między światem widzialnym i niewidzialnym (Pomian 1996: 12). Przedmioty „stają się pośrednikami między tymi, którzy je oglądają, a światem, który reprezentują" (Pomian 1996: 35-36). Według tegoż autora materialny przedmiot, który jest widziany przez widza, odsyła go do swojej niematerialnej reprezentacji (Pomian 1996: 39-40, 48). Mediowanie między tymi światami jest więc główną funkcją wyeksponowanych przedmiotów, które mediują dopiero wówczas, gdy są oglądane. Przedmiot, jako medium, wyraża się dopiero w relacji z człowiekiem w całym kontekście wystawy, niejako zależny jest on od ludzkich zachowań i aktywności. Obiekty zebrane na wystawach mają przedstawiać swoisty świat rzeczywisty w możliwie jak najbardziej skondensowanej formie. Wystawa jest więc niejako pomniejszonym światem, mikrokosmosem, który odnosi się do swojej szerszej prezentacji w świecie, zarówno w aspekcie widzialnym, jak i niewidzialnym (Pomian 1996: 91-102).

Przedmiot umieszczony na wystawie zmienia również swój dotychczasowy status. Wyłącza się go bowiem z użytkowania i umieszcza w gablotach, przeznaczając go wyłącznie do oglądania. Oglądane rzeczy nie spełniają żadnej funkcji użytkowej, a mimo to są one otaczane troską, opieką i ochroną, są odpowiednio zabezpieczane, czyszczone, a gdy się uszkodzą, są również naprawiane (Pomian 1996: 16). Szczególnym powodem owej troski jest ich wartość znaczeniowa, która w tym wypadku jest bezcenna (Pomian 1996: 16-19).

W kluczu tych rozważań zwyczajne rzeczy użytkowane przez Karola Wojtyłę (Jana Pawła II) umieszczone w obrębie muzealnej wystawy zmieniają całkowicie swoje pierwotne znaczenie. Na wystawie, zdawać by się mogło, zwykłe meble czy przedmioty codziennego użytku niejako zatracają swoje znaczenie ze względu na dawnego właściciela, a dodatkowo umieszczone w obrębie całej narracji mają odnosić widza do swojej reprezentacji, którą w tym przypadku jest postać Karola Wojtyły (Jana Pawła II), to znaczy ukazywać jego sylwetkę, osobowość, cechy charakteru, życie prywatne itp.

Analogiczne rozważania względem reprezentatywnego charakteru i pośredniczącej funkcji obiektów przeprowadza Anna Wieczorkiewicz. Autorka uważa, że muzea, tworząc wystawę, nadają jej intencjonalnie z góry ustaloną narrację. Do takiej właśnie narracji służą odpowiednio dobrane i ukazane przedmioty, które odczytuje się według klucza zaproponowanego przez kustoszy i kuratorów wystawy (Wieczorkiewicz 2000: 17). Zadaniem muzeum jest więc prezentacja danego wycinka rzeczywistości, zaś zadaniem tworzących wystawę - odpowiednie 
przygotowanie miejsca na relację widz - obiekt (Wieczorkiewicz 2000: 16) oraz pośredniczenie w niej.

Posługując się gadamerowską metaforą gry, autorka zauważa, że wystawa, aby w ogóle zaistnieć, musi być grana przez jej użytkowników - autorów jako nadawców i widzów jako odbiorców. W innym wypadku stanowi ona zbiór niepowiązanych ze sobą przedmiotów. W oglądaniu i percypowaniu wystawy lokuje się jej odczytywanie i rozumienie (Wieczorkiewicz 2000: 19). Jednakże zwiedzając wystawę, widz nie musi ulegać narzuconemu dyskursowi i może samodzielnie interpretować to, co ogląda. Niektóre z przedmiotów mogą wywoływać w nim inne emocje i skojarzenia, niż zaplanował to autor wystawy. Jak pisze autorka: „Zwiedzający mogą [...] traktować kolekcje jak zbiory pamiątek, które przypominają im minione wydarzenia, ewokują pewne prywatne narracje i wzbudzają nostalgiczne uczucie w stosunku do przeszłości" (Wieczorkiewicz 2000: 17). W tym sensie spojrzenie odbiorcy przyjmuje formułę dialogiczną. Podejmuje on bowiem interakcję (dialog) z obiektem, który widzi, ale również przedmiot może wywołać jego wewnętrzny dialog z samym sobą. Widz może też odczytać tekst wystawy wbrew autorskim zamysłom, wraz z błędami lub nadużyciami w interpretacji wypaczającymi pierwotny sens wystawy (Wieczorkiewicz 2000: 17-18). Podstawowym elementem wywołującym ową dialogiczną interakcję jest natomiast przedmiot. Przedmioty, jak pisze Wieczorkiewicz, „wskazują na coś poza nimi samymi - ich muzealny byt wyprowadza swe spełnienie z ukazania tego reprezentatywnego charakteru. Reszta zależy od tego, co dokonuje się w dialogicznym stosunku pomiędzy zwiedzającym a przedmiotem" (Wieczorkiewicz 2000: 19). Wystawa według tej autorki ma tym samym dwie płaszczyzny: swoją własną („tu i teraz”) oraz rzeczywistość prezentowaną, do której się odnosi (Wieczorkiewicz 2000: 19).

Jak wspomniałem wcześniej, muzea są również elementem szerszych rozważań dotyczących turystyki. Na przykład John Urry podkreśla, że muzea zawsze były zorientowane na przeszłość, a historia jest jednym $\mathrm{z}$ ważniejszych tworzyw turystycznej adaptacji. Turysta, jako kluczowa dla jego analiz postać społeczna, chce poznać dane miejsce i go doświadczyć, a przodującym w jego percepcji jest zmysł wzroku. Pragnie on zobaczyć nowe miejsce, pożądając zawsze nowych wrażeń wzrokowych (Urry 2007: 189). Jak pisze sam autor: „W rzeczywistości, zwłaszcza jako turyści, «widzimy» obiekty, którym został przypisany sens, obiekty, które znaczą coś innego niż one same" (Urry 2007: 190).

W oczach turysty muzeum jest instytucją autorytatywną, której specyfikę bez wątpienia podkreśla "historyczna autentyczność zgromadzonych eksponatów” (Urry 2007: 190-191). Jednak współczesne muzea, według badacza, zmieniły swój dotychczasowy wygląd i charakter - poprzez nowy sposób pojmowania historii zaczęto tworzyć nowe, alternatywne wystawy. „[...] historia przez duże «H» zmieniła się na wiele mniejszych, w dodatku «uwspółcześnionych» historii. [...] Muzea służą pokazywaniu historii, co oznacza, że historii wartych pokazania znacząco przybywa" (Urry 2007: 191). Wskutek przewrotu postmodernistycznego 
przestała obowiązywać jedna, oficjalna, autorytarna wersja historii, a w wyniku fragmentaryzacji i polifoniczności zaczęto odczytywać i tworzyć nowe historie. Przewrót ten dotknął również muzea, które przekształciły się z muzeum historii (historia w liczbie pojedynczej) w muzea historii (historia w liczbie mnogiej). Właśnie takie muzea stały się bardziej zachęcające dla turystów, którzy poszukują w doświadczaniu nowych miejsc atrakcyjności i autentyczności. Według tegoż socjologa postmodernistyczny zwrot w muzeach można określić jako przejście „od aury do nostalgii" (Edgar 1987, za: Urry 2007: 192). Postmodernistyczny antyelitaryzm traktuje bowiem wszystkie obiekty tak samo i na równi postrzega wielkie dzieła sztuki z narzędziami robotniczymi (Urry 2007: 192). Tym samym" nastąpiła również fascynacja zwykłym życiem.

Można odnieść wrażenie, że im bardziej dramatyczna przeszłość, tym bardziej autentyczne, sugestywne i atrakcyjne turystycznie muzeum, lecz ludzi nie interesują już wyłącznie wielkie dzieła sztuki. Coraz bardziej są ciekawi, jak wyglądało „zwykłe życie”, skromne domostwa i codzienne zajęcia (Urry 2007: 191).

Według Anny Wieczorkiewicz natomiast muzeum proponuje zobaczenie i zrozumienie odległej od nas rzeczywistości zarówno w wymiarze czasowym, jak i przestrzennym (Wieczorkiewicz 2008: 48). Eksponat bowiem wikła widza w doświadczenie przeszłości.

W obiekcie zawiera się obecność, obecność ludzka - rysy twarzy na masce pogrzebowej, odcisk kciuka na garnku. Poprzez tę obecność konstytuuje się autorytatywność obiektu i jego autentyczność. Obecność przeszłości - przeszłość trwa i sięga ku nam, dotykając nas (Shanks, Tilley 1987: 75, za: Wieczorkiewicz 2008: 49).

Z tej obecności wysnute są narracje mające unaocznić przeszłość i ożywić pewne znaczenie tak, by stały się one częścią naszych doświadczeń. Otwierają się przed nami „inne światy” - przeszłość wzięła nas w posiadanie (Wieczorkiewicz 2008: 49).

Stare, bezużyteczne przedmioty w momencie umieszczenia ich na wystawie zyskują zupełnie nową wartość. Stają się „oryginalne” i „autentyczne”, a tym samym wzmacniają analogiczne cechy całej wystawy. Przedmioty te mają bowiem w sobie ślady dawnych użytkowników, a przez to nie tylko unaoczniają przeszłość, ale również pozwalają jej doświadczyć i zaświadczają o autentyczności tego doświadczenia (Wieczorkiewicz 2008: 163).

Zebrane w krakowskich muzeach często bardzo osobiste rzeczy i pamiątki Karola Wojtyły (Jana Pawła II) poza swoją prymarną reprezentacyjną funkcją mediują też na inne sposoby. Idąc tropem przytoczonych rozważań: przedmioty te często ukazują bardzo prywatną sferę życia. Jak to określił John Urry, zainteresowanie zwykłym życiem dotyczy również zwykłego życia wielkich lokalnych osobistości. Przedmioty te, jak np. zużyta portmonetka, drewniane chodaki czy stare fotografie, niewątpliwie noszą na sobie osobisty ślad dawnego ich użytkownika. Częstokroć również wprawiają one widza we wspomnianą przez Wieczorkiewicz 
dialogującą grę, wywołując odpowiednie wspomnienia czy refleksje. Kluczową i nadrzędną w moim odczuciu kategorią jest tutaj jednak zaznaczana wcześniej potrzeba autentyczności. Przedmioty-relikwie zaświadczają bowiem o „prawdziwości” danej historii i danego miejsca. Oglądając wystawę muzealną, widz niejako zawierza się instytucji i przyjmuje „na słowo”, że tak rzeczywiście było. Dają one dostęp do niedostępnej przeszłości, w której Karol Wojtyła (Jan Paweł II) był fizycznie obecny.

Współcześnie coraz częściej zwraca się również uwagę na procesualny wymiar koncepcji muzeum. Ciekawy artykuł dotyczący „muzealizacji” i „muzealifikacji”, wpisujący się w ten nurt badań, opublikowali Maria Adinolfi i Mattijs van de Port, którzy opisali proces i zjawisko przekształcania prywatnych mieszkań ważnych osobistości (w tym także religijnych) na muzea na przykładzie mieszkania kapłanki Candomble - Mãe Menininha, której prywatne mieszkanie w Salwatorze przekształcono w muzeum.

Fenomen przekształcania mieszkań „wyjątkowych ludzi” w muzea jest powszechnie znany. Na całym świecie biura ważnych przywódców politycznych, atelier uznanych malarzy, a także domy, w których pisarze stworzyli swoje słynne powieści, są „otwarte dla publiki”. Wizyta w takich miejscach jest określana jako możliwość zetknięcia się z codziennym życiem postaci historycznych, poczucia przyziemnego otoczenia wielkości, spotkania się z tym, co Richard Dyer nazwał „niezwykłą zwykłością” [lub „niecodzienną codziennością”] (Adinolfi, van de Port 2013: 285; tłum. własne).

Wizyta w takim backstage życia ważnej osobistości umożliwia zobaczenie nie tylko jej domu, ale również jej życia prywatnego, prowadzonego poza kulisami życia publicznego, gdzie nie jest ona zobowiązana do odgrywania określonych ról społecznych. Dom jest przestrzenią prywatną, w której nawet celebryta może pozostać „autentycznym sobą”. Odwiedzenie takiego domu-muzeum jest zarazem spotkaniem z „prawdziwym” życiem właściciela, interpretowanym przez badaczy jako intymne spotkanie $\mathrm{z}$ tą osobą (Adinolfi, van de Port 2013: 285-286). Oddziaływanie takiej wystawy toczy się w relacji między zwiedzającymi a obiektami. Prywatny dom zmienia się w wystawę, a codzienność domowników w spektakl. $\mathrm{Z}$ racji jednak tego, że podstawową materią „muzealizacji” są miejsca i przedmioty silnie spersonalizowane, całe muzeum siłą rzeczy przejmuje cechy danej postaci. „Muzea sławnych ludzi mają zatem podnieść normalność i nadać jej aurę nadzwyczajności” (Adinolfi, van de Port 2013: 287, tłum. własne).

Muzea typu „dom wielkiego człowieka” to „połączenie najbardziej prywatnej i publicznej przestrzeni, to swoiste zamienienie «backstage» $\mathrm{W}$ «frontstage»" (Adinolfi, van de Port 2013: 294; tłum. własne). Dają one publiczny dostęp do „życia tak, jak żyli sławni ludzie". Poprzez odpowiednią personalizację ukazują prywatność konkretnej osoby i utrwalają pamięć o niej. Częstokroć odtworzone ponownie przez muzealników pomieszczenia, poza zachowaniem ich oryginalności, zawierają również elementy teatralizacji, poprzez którą kreuje się dynamikę miejsca. $\mathrm{Z}$ tego też powodu ubrania i przedmioty zwykle układa się i eksponuje w taki spo- 
sób, by widz miał wrażenie, że gospodarza domu nie ma w nim tylko na chwilę. „W ten sposób niektóre ubrania zostały przewieszone przez oparcia, a odsunięte krzesło sugeruje, że "wyszła tylko wziąć prysznic i zaraz wróci»" (Adinolfi, van de Port 2013: 296, tłum. własne). Pomieszczenie dzięki takim działaniom proponuje widzom intymne spotkanie $\mathrm{z}$ „wielką personą, dając niejako „przywilej udostępniania prywatnego pokoju" (Adinolfi, van de Port 2013: 296, tłum. własne).

Analogicznie twierdzi również Dean MacCannell, który zauważa dramatyzację wystaw muzealnych, paralelnie do dawnych praktyk religijnych. Muzeum, według tegoż badacza, stwarza rodzaj swoistego widowiska, podczas którego przedmioty, oddziałując poprzez wzrok, poruszają wyobraźnię widza (MacCannell 2005: 124).

Tak steatralizowana przestrzeń muzealna częstokroć potęguje doświadczenie odbioru wystawy i wzmacnia reprezentacyjną funkcję zgromadzonych obiektów. Dla tych, którzy mieli okazję spotkać się z Wojtyłą (Janem Pawłem II) za jego życia, przywołuje odpowiednie wspomnienia, dla młodszych pokoleń natomiast odpowiednio zaprojektowana wystawa pozwala przeżyć takie spotkanie po raz pierwszy w życiu, pomimo fizycznej nieobecności papieża.

Muzeum jest również silnym narzędziem ideologicznym i równie dobrym narzędziem komunikacyjnym. Dzięki swojej autorytatywnej mocy muzeum jest nie tylko szerokim medium przekazu społecznego, ale także strażnikiem zapewniającym prezentowanym treściom szacunek (Adinolfi, van de Port 2013: 288-290). Narracja muzealna może również otwierać przestrzeń na inne niż zakładane interpretacje, stając się tym samym przestrzenią konfliktów, co wykazał w swoich badaniach nad wystawami muzealnymi Geoffrey White (zob. White 1997). Sam język muzealny, który wydawać by się mogło, że powinien być przypisany sferze profanicznej, może pozostać językiem sakralizacji. Omawiany typ muzeum ukazuje również z pozoru zwyczajne rzeczy codziennego użytku $\mathrm{w}$ ich podwójnym znaczeniu. „Muzealizacja” przedmiotów przedstawia bowiem często obie strony - sakralną i profetyczną - zebranych obiektów (Adinolfi, van de Port 2013: 300-302).

Muzea ukazują obiekty pamięciowe związane ze sferą świętą [...] bez zderzenia między potencjalnie profanującym językiem „muzealnym” i językiem sakralnym. Wręcz przeciwnie, wspomniana „muzealizacja” pomaga ludziom wyrazić swoje wartości religijne w uznanym społecznie języku (Adinolfi, van de Port 2013: 301-302, tłum. własne).

Podsumowując powyższe propozycje badawcze i analityczne wystaw muzealnych, stwierdzam, że muzeum jawi się jako instytucja publiczna obdarzona szacunkiem społecznym wynikającym z jej niekwestionowanego autorytetu. $\mathrm{Na}$ mocy swojej pozycji orzeka nie tylko o wartości kolekcjonowanych i pokazywanych obiektów, ale również zaświadcza o ich autentyczności i prawdziwości. Zebrane obiekty autorzy wystaw wykorzystują do kreacji odpowiedniej narracji wystawy, częstokroć narzucając też odpowiednią, ustaloną z góry ich interpretację. Wytwarzany przez muzea produkt, jakim jest wystawa, nigdy nie istnieje sam 
w sobie. Aby tekst i sens wystawy mogły zaistnieć, to znaczy być odczytane, potrzebuje ona odbiorców. Najważniejsze jednak miejsce w całej wystawie zajmuje przedmiot, który jest reprezentacją swojego szerszego znaczenia, odnosząc się do całej sfery znaczeń i sensów. Ma on w ustalonej przez autorów wystawy formie przywoływać odpowiednie skojarzenia ze swoimi rzeczywistymi odnośnikami. Analogicznie sama wystawa jest wyłącznie fragmentem rzeczywistości, reprezentującym szerszy jej kontekst $\mathrm{w}$ realnym świecie. Jest swoistym mikrokosmosem reprezentującym makrokosmos. Uszczegóławiając te rozważania w zakresie niniejszego artykułu - każde z krakowskich muzeów prezentujących postać papieża-Polaka jest mikroreprezentacją danego wycinka życia Karola Wojtyły (lub Jana Pawła II) i opowiada jego historię poprzez odpowiednie relikwie-przedmioty. Tym samym zaświadczają one o autentyczności jego osoby i uobecniają go (przywołują wspomnienia, pokazują, ,jaki był naprawdę", ,jakie życie prowadził”).

$\mathrm{Na}$ terenie Krakowa funkcjonuje aż siedem muzeów poświęconych Karolowi Wojtyle (Janowi Pawłowi II). Każde z nich, ze względu na swoją przynależność instytucjonalną jak i własny charakter, prowadzi indywidualną narrację o papieżu-Polaku, przyjmując odmienne strategie działania. Chciałbym uważniej przyjrzeć się dwóm muzeum, traktując je jako jakościowe studia przypadków, aby ukazać różnorodność praktyk kreowania wystawowej narracji.

\section{Przypadek pierwszy: Centrum Jana Pawła II}

Część muzealna przy Centrum Jana Pawła II „Nie lękajcie się!” w Borku Fałęckim jest stosunkowo nowa. Muzeum działa tutaj bowiem od 23 czerwca 2013 roku i jest jednym z oddziałów Muzeum Archidiecezjalnego Kardynała Karola Wojtyły w Krakowie.

Muzeum składa się z czterech pomieszczeń. Wchodząc do pierwszej sali, zauważa się stojącą na środku gablotę, w której zaprezentowano trzy stroje papieskie. Znajdują się tu również dwa płaszcze - jeden zwykły, codzienny, koloru białego i drugi czerwony o charakterystycznym kroju peleryny z czerwonym kapeluszem. Kolejne gabloty rozlokowane wzdłuż ścian pomieszczenia prezentują różnorakie pamiątki: dary zarówno od osób prywatnych, jak i od głów państw: medale pontyfikalne, krzyże pektorale, kielichy, medale sportowe oraz tace. Na szczególną uwagę zasługują gabloty z pamiątkami osobistymi Jana Pawła II, wśród których można znaleźć: zegarek, szklankę, papieską serwetkę, chusteczkę z herbem JPII, brewiarz, osobisty różaniec czy zdjęcie matki z albumu rodzinnego. Następnie przechodząc przez długi korytarz, dochodzi się do drugiej, znacznie większej sali wystawowej. Wybudowane na planie pięcioboku pomieszczenie jest otwarte na wysokość dwóch pięter. Jego środek wyznacza otwarta przestrzeń, wokół której biegną na poziomie pierwszego piętra antresole, stąd można zobaczyć, wychylając się przez barierkę, co znajduje się na dole w samym centrum sali. A umieszczono 
tu dwa interesujące obiekty: tron papieski z dwóch ostatnich pielgrzymek Jana Pawła II do Polski z 1999 i 2002 roku oraz stół z położonym białym obrusem przykrytym plastikową folią i postawionym na nim: „Fragment[em] zastawy stołowej używanej przez Ojca Świętego Jana Pawła II z Pałacu Apostolskiego w Watykanie”. Dookoła nich stoją dwa rzędy gablot ułożonych według pewnego porządku. Pierścień wewnętrzny gablot stanowią przedmioty używane przez Jana Pawła II, natomiast pierścień zewnętrzny tworzą liczne gabloty z darami i prezentami, które otrzymał podczas zagranicznych pielgrzymek apostolskich. Gabloty te sklasyfikowano względem miejsc geograficznych, mapując za pomocą wystawionych w nich przedmiotów szlaki papieskich kontaktów.

Węższy krąg gablot zajmują stroje i przedmioty, których Karol Wojtyła/Jan Paweł II używał za swojego życia. Można w nich zobaczyć gablotę z sutanną kardynalską i kardynalskim strojem chóralnym z czerwonym biretem oraz gablotę z ornatem, kielichem, bielizną i welonem kielichowym z prywatnej kaplicy z pałacu biskupiego w Krakowie. W dalszej kolejności prezentowane są dwa ornaty oraz pięć pastorałów, które Jan Paweł II otrzymał w prezencie. Ostatnia gablota zamykająca półokrąg jest poświęcona jego aktywnościom sportowym. Znajdują się w niej para nart firmy Fischer z kijkami, biała kurtka narciarska, wysokie białe buty zimowe, para skórzanych sandałów, czarno-żółty plecak, zielona torba i narciarskie gogle.

Dalej w głębi tego wielkiego pomieszczenia usytuowano zrekonstruowany „pokój Kardynała Karola Wojtyły”, a tuż przed nim kolejną, ostatnią już gablotę z jego dokumentami nominacyjnymi.

Wojtyła wraz z otrzymaniem nominacji kardynalskiej z rąk papieża Pawła VI 28 czerwca 1967 roku zmienił również swoje miejsce zamieszkania w Krakowie. Do końca roku 1967 mieszkał w kamienicy Dziekańskiej przy ulicy Kanoniczej 21, później natomiast przeniósł się do Pałacu Arcybiskupów Krakowskich przy ulicy Franciszkańskiej 3, w którym miał również swój prywatny pokój (Nowobilski 2011: 31-35). Mieszkał tutaj przez kolejne jedenaście lat, aż do wyboru na papieża 16 października 1978 roku. Później pokój ten zamieszkiwał sporadycznie już jako Jan Paweł II za każdym razem, gdy gościł w Pałacu Arcybiskupim w Krakowie. Pałac Arcybiskupi nie posiada stałej ekspozycji muzealnej, więc pokój ten został odtworzony w omawianym muzeum przy Centrum Jana Pawła II.

Rekonstrukcja tego pokoju mieści się w osobnym pomieszczeniu, ulokowanym między korytarzem a salą wystawową, i ma częściowo przeszklone ściany, dzięki czemu „pokój kardynalski” można oglądać z trzech stron. Ekspozycja ta jest przestrzenią symulakryczną (zob. Baudrillard 2005), która poprzez zabiegi wystawiennicze i ukazywane w niej obiekty nabiera cech autentyczności. Jednakże w przeciwieństwie do innych wystaw ukazujących pokoje Wojtyły ${ }^{2} \mathrm{w}$ tym pokoju w rzeczywistości Karol Wojtyła nigdy nie mieszkał. Jest on wyłącznie

2 Chodzi o Muzeum Mieszkanie Wojtyłów przy ulicy Tynieckiej i o Pokój księdza Wojtyły w Muzeum Archidiecezjalnym Kardynała Karola Wojtyły przy ulicy Kanoniczej. 
przestrzenią odtworzoną z mebli, które były wyposażeniem „prawdziwego” pokoju w Pałacu Arcybiskupim. Podpis muzealny informuje, że jest to: „Wyposażenie pokoju z Pałacu Arcybiskupiego przy ulicy Franciszkańskiej 3, w którym [Karol Wojtyła] również jako papież Jan Paweł II zatrzymał się podczas pielgrzymek do Polski, odwiedzając Kraków”. W odbiorze wizualnym, zapośredniczonym przez szybę, pokój sprawia wrażanie „autentyczności”, gwarantowanej przez autorytet instytucji muzealnej. W moim odczuciu wygląda tak, jakby był przeniesieniem pokoju w proporcji jeden do jednego wraz z układem, ścianami, sufitem i podłogą, chociaż zdawałem sobie sprawę z tego, że jest to wyłączne rekonstrukcja wnętrza $\mathrm{z}$ dawnego pokoju kardynalskiego przy ulicy Franciszkańskiej. W tym niewielkim pomieszczeniu wstawiono masywne biurko z krzesłem, na którym stoi metalowy krucyfiks, figura Madonny, fotografia w ramce, abażurowa lampa oraz świeczka. Tuż obok niego, w rogu, krótkie łóżko z dywanem naściennym i obrazem Madonny Częstochowskiej. Następnie, wzdłuż ściany stoi klęcznik, na którym położono otwarty brewiarz, dalej duża szafa i szafka na buty oraz wieszaki. Na przeciwległej ścianie ulokowano mały stół z bardzo prostą zastawą śniadaniową z Pałacu Arcybiskupiego (z charakterystycznymi szklankami ze spodkiem). Poza tym w pokoju stoi jeszcze masywny drewniany pulpit z umieszczoną na nim Biblią oraz na dostawianym stoliku mała walizka na przybory toaletowe, używane przez Jana Pawła II podczas podróży.

Wystawa muzealna przy Centrum Jana Pawła II jest rozwinięciem innych krakowskich wystaw, szczególnie zaś Muzeum Archidiecezjalnego przy ulicy Kanoniczej, którego jest filią, z kilkoma znaczącymi zmianami. Przede wszystkim istotny jest tutaj regularny układ przestrzenny, który daje swobodę w poruszaniu się po muzeum. Układ przestrzenny klasyfikuje również rangę przedmiotów, w obu salach bowiem obiekty rozlokowano z drobnymi wyjątkami według tej samej zasady: w centrum umieszczano te przedmioty, których Karol Wojtyła/Jan Paweł II używał (stroje liturgiczne, rzeczy codziennego użytku), a na zewnątrz nich prezentowano zazwyczaj tak zwane „dary papieskie”. Szczególnym zaś miejscem muzeum jest symulakryczna przestrzeń „pokoju Kardynała Karola Wojtyły", która certyfikowana autorytetem muzealnym powinna wzmacniać wrażenie „autentyczności”. Drobne rzeczy osobiste umieszczone wewnątrz niego, takie jak para kapci przy łóżku, otwarty brewiarz, powieszony na wieszaku płaszcz, oparta o łóżko laska czy fotografia na biurku, mają przekonać widza, że właściciela tego mieszkania tylko chwilowo nie ma. Przez moment znów odnosi się wrażenie zatrzymanej chwili - mieszkaniec pokoju dopiero wyszedł, a pokój „czeka” na jego powrót. Jest to zarazem możliwość bardzo intymnego spotkania z postacią gospodarza, jak zaświadcza np. jeden z opisów tego miejsca z pamiątkowego albumu, zachęcającego do jego odwiedzenia:

Najcenniejsze są jednak w takich miejscach bez wątpienia rzeczy noszące osobiste piętno Jana Pawła II. Jakże wzruszające są rozchodzone czarne półbuty, pewnie jeszcze z czasów krakowskich, podróżny kuferek z przyborami toaletowymi, sutanny z różnych okresów, otwarty bre- 
wiarz. Można tam też odnaleźć biały płaszcz papieski z cieplejszego materiału, który widoczny jest choćby na zdjęciach z podróży Ojca Świętego do Japonii. Dobrze znajoma jest także długa czerwona peleryna i takiż czerwony kapelusz, które miał na sobie podczas podróży do Meksyku w 1979 roku. A cóż powiedzieć o nartach, plecaku, i białej kurtce podczas pobytu w górach, między innymi podczas wakacyjnego odpoczynku w Dolinie Aosty. W innym miejscu znalazły się kryształowa szklanka, serwetka obiadowa oraz chusteczka do nosa opatrzona monogramem Jana Pawła II (Sosnowska 2015: 35).

Pod nieobecność właściciela dzięki przeszklonym fragmentom ścian można (wścibsko, ale za prawomocnym przyzwoleniem) podejrzeć, jak kardynał mieszka(ł) lub co robi(ł). Jednak szklana granica pomieszczenia nieznacznie falsyfikuje w percepcji wrażenie „powrotu właściciela”. Przez nią pokój przypomina rodzaj akwarium, przeszklonego panoptikonu, w którym można obserwować $\mathrm{z}$ trzech stron całe pomieszczenie bez ani jednego miejsca niewidocznego. Tak zdehumanizowana przestrzeń stopniowo zaczyna podlegać chłodnemu, obiektywnemu oglądowi. Widz zdaje sobie sprawę z tego, że realnie nie jest to miejsce możliwe do zamieszkania. Całe początkowe wrażenie „odwiedzenia prywatnego pokoju” w końcu gdzieś umyka. Dalej jednak „autentyczność” tego miejsca zaświadczają zebrane w nim przedmioty-relikwie. Muzeum działające przy Centrum Jana Pawła II staje się więc miejscem wykreowanym, stworzonym, można by powiedzieć, na martwym korzeniu, które powstało w wyniku ogólniejszego zamysłu instytucjonalnego. Stąd stosowane zabiegi wystawiennicze, które mają przybliżać widza do osobistej i prywatnej przestrzeni świętego poprzez rekonstrukcję i symulakryczność miejsca.

\section{Przypadek drugi: Muzeum Lotnictwa Polskiego}

Ciekawą i unikatową pamiątkę po Janie Pawle II prezentuje Muzeum Lotnictwa Polskiego ${ }^{3}$, które działa od lat 60 . XX wieku i którego strategia względem obiektu-relikwii jest odmienna niż w przypadku Centrum Jana Pawła II.

W 2008 roku muzeum to wzbogaciło się o nowy obiekt - śmigłowiec Mil Mi-8S o numerze bocznym 620. Egzemplarz ten wyprodukowany został w Kazańskich Zakładach Śmigłowcowych w 1973 roku w wersji „salonka” dla dziesięciu osób. Służył w 36. Specjalnym Pułku Lotnictwa Transportowego w Warszawie, w jednostce wojskowej 2139, z której został wycofany i przeznaczony do kasacji w 2008 roku. Muzeum Lotnictwa Polskiego starało się o pozyskanie tego modelu, by uzupełnić wystawę o śmigłowiec pasażerski z możliwością zwiedzania jego wnętrza. Ostatecznie maszynę przekazano 16 grudnia 2009 roku (www.muzeumlotnictwa. pl, dostęp: 19.12.2017).

3 Serdeczne podziękowania w tym miejscu składam pracownikom Muzeum Lotnictwa Polskiego, Pani Katarzynie Zielińskiej i Panu Dariuszowi Rutkowskiemu, którzy zgodzili się podzielić się ze mną swoją wiedzą. 
Śmigłowiec, w malowaniu standardowym (biało-czerwonym z napisem Rzeczpospolita Polska) w wersji pasażerskiej, przetransportowano do muzeum na zimę i przez kolejne kilka lat kompletowano potrzebne części oraz remontowano go. W międzyczasie pracownik muzealny przeglądając zdjęcia $\mathrm{z}$ wizyt Jana Pawła II w Polsce, dostrzegł, że jeden ze śmigłowców transportujących papieża ma numer boczny 620. Autorem fotografii był Andrzej Winiarski - jeden z pilotów (zob. Radwan 2014: 6-7), który potwierdził, że ten konkretny egzemplarz śmigłowca transportował Jana Pawła II podczas jego pielgrzymek do Polski. Identyfikacja śmigłowca na innych zdjęciach była trudniejsza. Po pierwsze kadr zazwyczaj obejmował przód śmigłowca, bez jego ogona, na którym wypisany jest numer boczny. Po drugie dlatego, że śmigłowiec był wielokrotnie remontowany, w tym również przemalowywany (w latach 70. np. latał w barwach biało-niebieskich Polskich Linii Lotniczych LOT). Ostatecznie okazało się, że na pokładzie właśnie tego śmigłowca podróżował Jan Paweł II podczas swoich pielgrzymek do ojczyzny w 1983 i 1997 roku. W taki sposób, przez zupełny przypadek, odkryto historię na pierwszy rzut oka „typowego” obiektu. Wówczas muzeum postanowiło odtworzyć perypetie śmigłowca. Nagłośniono w mediach publicznych historię muzealnego egzemplarza z prośbą o pomoc w przywróceniu jego wyglądu z czasów, gdy podróżował nim papież. W taki sposób do muzeum zgłosiło się wiele osób prywatnych i firm, które w czynie społecznym chciały zaangażować się w projekt. Na przykład Przedsiębiorstwo Usług Komunalnych Artur Zys zapewniło malowanie śmigłowca, pokrywając równocześnie jego koszty, natomiast transport maszyny do lakierni w Pławcach nieodpłatnie wykonała firma Przemysława Panasa „Panas Transport”. Muzeum próbowało również odtworzyć wnętrze samolotu w typie „salonka”, gdyż w takim wnętrzu podróżował papież. Znaczną część wyposażenia salonki udało się uzyskać od lotniska Balice, a do otworzenia jej wnętrza zobligowała się w czynie społecznym firma tapicerska MSincognito Mariusza Sosnowskiego. Śmigłowiec (również w środku) miał być udostępniony zwiedzającym, dlatego też niezbędne było odpowiednie zabezpieczenie skórzanej tapicerki. Na sam koniec remontu, w 2014 roku, udało się pozyskać komplet łopat oraz dwa fotele $\mathrm{z}$ innego śmigłowca. $\mathrm{W}$ tym roku również kompletny, wyremontowany i odnowiony „Śmigłowiec Papieski” trafił na ekspozycję stałą Muzeum Lotnictwa Polskiego. Przez pierwszy rok eksponowano go wraz z pożyczonymi z lotniska w Dęblinie schodkami papieskimi, które się tam zachowały. W kolejnym roku Muzeum wykonało replikę schodków, z którymi śmigłowiec jest wystawiony do dziś.

Maszyna lotnicza pokazywana jest na wystawie stałej zaraz przy nowym budynku głównym muzeum. W pełni wyposażony śmigłowiec można oglądać z zewnątrz przez cały czas otwarcia muzeum, jego wnętrze natomiast udostępniane jest zwiedzającym wyłącznie w określonych godzinach. Pomalowany w barwach biało-czerwonych, $\mathrm{z}$ napisem Rzeczpospolita Polska śmigłowiec oznaczony jest dodatkowymi emblematami, m.in. herbem papieskim przy drzwiach. Wchodząc zaś do jego wnętrza, można przez otwarte drzwi zajrzeć do kokpitu oraz wejść do 
salonki. Jest to małe pomieszczenie z wyścielonymi ścianami i sufitem, w którym po lewej stronie, wzdłuż całej ściany, ciągnie się długa kanapa z ciemnobrązowej skóry z pasami bezpieczeństwa. Po przeciwnej zaś stronie stoją dwa duże fotele, w takim samym stylu co kanapa, zwrócone ku sobie. Na podłodze w głównym przejściu umieszczono dywany, okna natomiast udekorowano białymi firankami powieszonymi na złotych karniszach. Przy drzwiach powieszono również herb papieski po lewej i godło Polski po prawej stronie. Dopełnieniem całej ekspozycji jest telewizor umieszczony w rogu salonki, na którym wyświetlana jest prezentacja zdjęć z podróży papieża śmigłowcem podczas jego apostolskich pielgrzymek w Polsce. Również na zewnątrz pokazywanemu eksponatowi towarzyszą liczne tablice informacyjne wraz z materiałem wizualnym.

Wyremontowanie i wyeksponowanie śmigłowca papieskiego w 2014 roku zbiegło się z innym ważnym wydarzeniem związanym z postacią Jana Pawła II, a mianowicie jego kanonizacją 27 kwietnia 2014 roku. Dlatego też, kiedy muzeum wyemitowało $\mathrm{w}$ mediach prośbę o wsparcie w rekonstrukcji śmigłowca, wiele osób zgłaszało się z ofertą bezpłatnej pomocy, traktując papieski śmigłowiec jako cenną pamiątkę i niezwykle ważny projekt. Przedmiot wraz ze swoją historią wywołał lawinę wspomnień. Popularyzatorska publikacja wydana przez Muzeum Lotnictwa Polskiego dotycząca obiektu zawiera liczne wspomnienia osób w różny sposób z nim związanych. Między innymi pilotów, fotografów, sponsorów, a nawet lokalnych polityków i przedstawicieli instytucji, np. wspomnienia Jacka Sarosieka:

Bardzo mnie poruszył dzisiejszy felieton z porannego TVN24, gdyż dotyczył śmigłowca, z którym związana była moja wieloletnia kariera w 36. SPLT. Faktycznie śmigłowiec ten brał udział w pielgrzymkach papieskich. [...] Wylatałem wiele godzin na tym śmigłowcu. [...] Śmigłowiec 620 od początku był w wersji Salon. Ta wersja, którą teraz posiadacie, to przeróbka po ostatnim remoncie. Zmiana wyposażenia była podyktowana tym, że 620-ka przekroczyła resurs w latach i już nie mogła wozić VIP. Zdjęto ławę dla ośmiu pasażerów, dwa fotele i stolik. Zdemontowano również ściankę oddzielającą wejście do śmigłowca od salonu. Pod koniec kariery był to najstarszy Mi-8 w naszym pułku i nosił pieszczotliwą ksywkę „BABCIA” (Radwan 2014: 13)

\section{oraz Artura Zysa:}

Podstawą istnienia każdego narodu jest pamięć o jego przeszłości. W naszej trudnej historii wiele razy zdarzyło się, że próbowano nam ją odebrać. Pozostaliśmy Polakami tylko dlatego, że nie zapomnieliśmy o tym, skąd się wzięliśmy i ile wspólnie przeżyliśmy. Jednym z elementów narodowej pamięci jest właśnie ten śmigłowiec papieski. Uznaliśmy, że kultywowanie pamięci o przeszłości w tej właśnie formie stworzy nowym pokoleniom szansę na poznanie historii (Radwan 2014: 21).

Historia opisanego wyżej obiektu muzealnego spowodowała wyłom w moich hipotezach badawczych. Początkowo byłem przeświadczony, że rzeczy używane przez papieża (szczególnie zaś te o wysokiej wartości materialnej, użytkowej czy znaczeniowej), gdy tylko wychodzą z użytku, są przez osoby prywatne i niektóre instytucje pieczołowicie przechowywane i ukazywane jako niezwykle cenne obiekty i pamiątki. Jednakże historia śmigłowca Mil Mi-8S pokazuje zupełnie 
inną możliwość losów „rzeczy dotkniętych i użytkowanych” przez świętego. Rzeczy takie mogą za życia świętego spełniać swoje funkcje, do których zostały stworzone, a fakt użytkowania ich nawet przez tak ważną osobę jak papież wpisuje się w ich codzienne, zwykłe wykorzystywanie. Dalsze losy takich przedmiotów mogą być różne. Okazuje się, że mogą one dalej prowadzić swój „zwyczajny” tryb funkcjonowania, mogą zostać zmienione czy nawet zapomniane, tak jak przez dłuższy czas śmigłowiec Mi-8 o numerze bocznym 620 .

Drugą rzeczą uderzającą w przytoczonej historii eksponatu jest zaangażowanie wielu osób i instytucji w odnowienie obiektu przy okazji „odkrycia” jego historii. „Papieski śmigłowiec” nie jest odgórnym, instytucjonalnym pomysłem „stworzenia" obiektu pasującego do całości wystawy, jest raczej oddolną inicjatywą zrzeszającą społecznie wiele osób, które chciałyby przywrócić zapomniane znaczenie danemu obiektowi. Pierwotnie miał to być po prostu eksponat egzemplarza śmigłowca Mi-8, ale stał się poprzez osobę papieża spersonalizowanym przedmiotem, „papieskim śmigłowcem”. Obiekt zamienił się tu w generator wspomnień, historii i anegdot, przypomnianych przez ludzi niegdyś z nim zawodowo związanych. Stał się nie tylko ważną pamiątką po Janie Pawle II, ale również skarbem dziedzictwa narodowego, konsolidującym Polaków jako element pamięci narodowej. Osoba papieża spersonalizowała maszynę, podnosząc znacząco jej rangę. Śmigłowiec przez to nie jest już tylko egzemplarzem konkretnego typu czy zabytkiem techniki lotniczej, ale staje się „śmigłowcem papieskim”, przedmiotem, poprzez który opowiadana jest kolejna opowieść o życiu i pontyfikacie Jana Pawła II. Jest przedmiotem pośredniczącym $\mathrm{w}$ upamiętnianiu i uobecnianiu świętego, który z kolei potwierdza jego autentyczność i nobilituje go, podnosząc do rangi niezwykłej pamiątki-relikwii.

\section{Wnioski}

Krakowskie wystawy muzealne poświęcone osobie Karola Wojtyły (Jana Pawła II) stanowią ważny, choć pozornie nieoczywisty fragment powszechnego w Krakowie (jak i w całej Polsce) kultu świętego Jana Pawła II. Krakowski kult tegoż świętego jest o tyle osobliwy, że w mieście tym przez wiele lat przebywał, mieszkał i pracował późniejszy papież i zawsze $z$ wielkim sentymentem wracał do niego podczas swoich podróży apostolskich. Miejsca i historie z nim związane nie należą jednak do porządku statycznej przeszłości, lecz poprzez rozmaite, bardzo dynamiczne procesy historia świętego papieża jest wciąż na nowo aktualizowana i przeżywana. Pomimo jego fizycznej nieobecności nadal uobecnia się jego postać. Przyczyniają się do tego w skali miejskiej chociażby wybudowane niedawno Centrum Jana Pawła II w Krakowie (zob. Niedźwiedź 2017b) czy doroczna pielgrzymka Śladami Karola Wojtyły Robotnika (zob. Niedźwiedź 2017a). 
Jednym z wymiarów tegoż procesu jest również muzealizacja. W jej centrum lokuje się przedmiot-relikwia. Rzeczy dawniej użytkowane przez Karola Wojtyłę (Jana Pawła II) stają się ze względu na swojego właściciela przedmiotami osobliwymi, a w kontekście muzealnej wystawy stanowią plastyczną materię do tworzenia i pokazywania opowieści o nim. Przedmiot-relikwia poddawany takim twórczym procesom oddziałuje na doświadczalną narrację wystawy. Między innymi poprzez proces dramatyzacji (zob. MacCannell 2005) czy teatralizacji (por. Adinolfi, van de Port 2013) przedmioty umieszczone w muzealnej gablocie mają dawać namiastkę spotkania z osobą papieża, do złudzenia przypominającą realne doświadczenie jego obecności. Zebrane na krakowskich wystawach przedmioty-relikwie i osobiste pamiątki Wojtyły (Jana Pawła II) noszą w sobie ślad swojego dawnego właściciela. Same w sobie będąc już rzeczą osobliwą, to jest szczególną ze względu na ich użytkownika, stają się przedmiotem mediującym, nie tylko odnoszącym się do swojej szerokiej reprezentacji, jak twierdzili Pomian i Wieczorkiewicz, ale również uobecniającym spotkanie widza $\mathrm{z}$ jego postacią $\mathrm{w}$ muzealnym "tu i teraz".

$\mathrm{Na}$ podstawie dwóch wybranych przypadków muzealnych zarysowuje się przykładowa narracja dotycząca postaci Karola Wojtyły (Jana Pawła II), jak i strategia jej kreowania. Wielopoziomowa religijna i sakralna historia Krakowa, której postać papieża stanowi jeden z ważniejszych elementów, jest rozmaicie ukazywana i wtapiana w tkankę miejską. Szczególnie zaś ważne wydają się instytucjonalne wymiary owych opowieści, prezentowane przez muzea, które historie te tworzą i prezentują. Dwa całkowicie różne przykłady ukazują nie tylko twórcze przekształcanie przedmiotu i kreowanie jego historii, ale także swoistą strategię jego ekspozycji. Przedmioty, które w przeszłości służyły papieżowi, stają się cenną pamiątką przywołującą wspomnienia jednego $\mathrm{z}$ ważniejszych świętych czczonych w Krakowie. Obiekty takie mogą być albo odgórnie - instytucjonalnie i autorytarnie - tworzone przez muzea poprzez wyciągnięcie ich z pierwotnego kontekstu i usytuowanie w sposób symulakryczny, jak w przypadku muzeum przy Centrum Jana Pawła II, albo ich historia za pomocą instytucji może zostać odkryta i stać się przyczynkiem wspólnych działań i konsolidacji rozmaitych osób w celu odtworzenia, zabezpieczenia i pokazania cennego w oczach konkretnych instytucji przedmiotu, czego przykładem jest „śmigłowiec papieski” w Muzeum Lotnictwa Polskiego.

Ważną część poczynionych analiz stanowi również upragniona przez turystów kategoria autentyczności. Autentyczność zebranych na wystawach pamiątek, podkreślona autorytetem instytucji muzealnej, niejako legitymizuje prawdziwość samej wystawy. Poświadczona oryginalność obiektów ukazuje, w domniemanym wrażeniu, że "tak było naprawdę". Dają one, po raz kolejny, uczucie doświadczenia uobecnienia ich dawnego właściciela i możliwość spotkania z nim. Przez strategię wystawienniczą to doświadczenie może ulec rozbiciu, jak w przypadku szklanej gabloty w pokoju kardynała Karola Wojtyły w muzeum przy Centrum 
Jana Pawła II, gdzie widz ma do czynienia z przestrzenią wykreowaną, symulakryczną, która ma legitymizować narrację muzealną. Zupełnie inną strategię zastosowano natomiast w przypadku Muzeum Lotnictwa Polskiego, które odkrywając przez przypadek historię jednego z obiektów kolekcji, udostępniło go szerszej publiczności i wspólnie z osobami prywatnymi i instytucjami przywróciło mu jego dawną postać. Wykreowana (czy w tym przypadku raczej odtworzona) opowieść przedmiotu stała się wspólnotowym procesem uobecniania i wspominania postaci papieża.

Relikwie-przedmioty są, w moim odczuciu, bardzo ważnym, choć nieoczywistym elementem krakowskiego kultu świętego Jana Pawła II. Kultu, który ma swoje znamiona religijne, analogiczne do kultu relikwii w obrębie murów kościelnych. Przedmiot-relikwia staje się swoistym medium, poprzez które widz nie tylko poznaje lokalne opowieści o Karolu Wojtyle (Janie Pawle II), ale również może doświadczyć jego uobecnienia.

\section{Bibliografia}

Adinolfi M., van de Port M., 2013 Bed and Throne. The „Museumification” of the Living Quarters of a Candomble Priestess, „Material Religion”, 9, s. 282-303.

Baudrillard J., 2005 Symulakry i symulacja, przeł. S. Królak, Warszawa.

Brzozowski G.,

2013 Spatiality and the Performance of Belief: The Public Square and Collective Mourning for John Paul II, ,Journal of Contemporary Religion”, 28, s. 241-257.

2014 Clashing Temporalities of Public Mourning. Warsaw after the Death of Pope John Paul II, „The Drama Review”, 58, s. 84-96.

Klekot E.,

2007 Mourning John Paul II in the Streets of Warsaw, „Anthropology Today”, 23, s. 3-6. Kubik J.,

1994 The Power of Symbols against the Symbols of Power: The Rise of Solidarity and the Fall of State Socialism in Poland, University Park.

Łozińska K.,

1990 Więc oto idzie papież słowiański. Romantyczne tło mitycznego wizerunku Jana Pawła II, „Prace Etnograficzne”, 27, s. 37-44.

1992 Jan Paweł II - bohater masowej wyobraźni, „Literatura Ludowa”, 36, s. 3-13.

MacCannell D.,

2005 Turysta. Nowa teoria klasy próżniaczej, przeł. E. Klekot, A. Wieczorkiewicz, Warszawa.

Niedźwiedź A., 2009 Mythical Vision of the City: Kraków as the 'Pope's City', „Anthropology of East Europe Review", 27, s. 208-226. 
2017a Framing the Pope Within the Urban Space. John Paul II and the Cityscape of Kraków, [w:] Spiritualizing the City. Agency and Resilience of the Urban and Urbanesque Habitat, eds. V. Hegner, P.J. Margry, New York, s. 81-101.

2017b The Multivocality of Space and the Creation of Heritages. New Shrines in an Old City, „Anthropological Notebooks”, 23, nr 3, s. 63-86.

Nowobilski A., 2011 Kanonicza kardynała Karola Wojtyły, Kraków.

Owczarek P., 2006 Karol Wojtyła - Jan Paweł II. Podhalańska opowieść o świętym. Od historii do mitu - studium antropologiczne, Kraków.

Pomian K., 1996 Zbieracze i osobliwości. Paryż-Wenecja. XVI-XVIII wiek, przeł. A. Pieńkos, Warszawa.

Radwan K. (red.),

2014 Papieski Śmigłowiec 620 w Muzeum Lotnictwa Polskiego, Kraków.

Sosnowska J.,

2015 Powrót na Białe Morza, [w:] Dom Świętego. Sanktuarium św. Jana Pawła II, red. A. Bujak, Kraków.

Urry J.,

2007 Spojrzenie turysty, przeł. A. Szulżycka, Warszawa.

Vergo P.,

2005 Milczacy obiekt, [w:] Muzeum Sztuki. Antologia, red. M. Popczyk, przeł. A. Łyda, Kraków, s. 313-334.

White G.

1997 Museum / Memorial / Shrine. National Narrative in National Spaces, „Museum Anthropology", 21, s. 8-27.

Wieczorkiewicz A.,

2000 Muzeum ludzkich ciał. Anatomia spojrzenia, Gdańsk.

2008 Apetyt turysty. O doświadczaniu świata w podróży, Kraków.

Zowczak M.,

1987 Jan Paweł II - narodziny legendy, „Literatura Ludowa”, 31, s. 3-12.

http://www.muzeumlotnictwa.pl/zbiory_sz.php?ido=278\&w=p (dostęp: 19.12.2017). 